\title{
New combinations in Hookerochloa and Poa (Gramineae)
}

\section{Surrey W.L. Jacobs' ${ }^{1}$ Lynn J. Gillespie ${ }^{2}$ and Robert J. Soreng ${ }^{3}$}

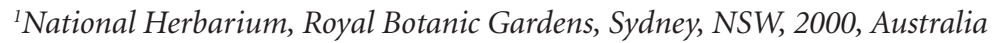 \\ ${ }^{2}$ Research Division, Canadian Museum of Nature, P.O. Box 3443, Station D, Ottawa, Ontario K1P \\ 6P4, Canada \\ ${ }^{3}$ Department of Botany, National Museum of Natural History, Smithsonian Institution, \\ Washington, DC 20013-7012 \\ Author for correspondence: surrey.jacobs@rbgsyd.nsw.gov.au
}

\begin{abstract}
The genus Austrofestuca is a synonym of Poa with its type species, A.littoralis - now a synonym of Poa billardierei. The combination P. pubinervis is made to place this closely related species with $P$. billardierei. The other two species, A. eriopoda and A. hookeriana belong together in the genus Hookerochloa and a new combination is provided for Hookerochloa eriopoda.
\end{abstract}

\section{Introduction}

Alexeev (1976) established Austrofestuca (Tzvelev) E.B.Alexeev from Festuca subgenus Austrofestuca, based on A. littoralis (Labill.) Alexeev. Clayton and Renvoize (1986) accepted Austrofestuca but stated that the characters used to delimit it required the inclusion of three more Australasian species. Simon (1986) provided the combination for A. pubinervis (Vickery) B.K.Simon, and Jacobs (1990) provided combinations for the remaining two, A. eriopoda (Vickery) S.W.L.Jacobs and A. hookeriana (F.Muell.) S.W.L.Jacobs.

Austrofestuca, Festucella E.B.Alexeev, Hookerochloa E.B.Alexeev, and Poa L. all belong to tribe Poeae subtribe Poinae which includes 15-21 genera as outlined by Soreng et al. (2007). While there had always been some thought that Austrofestuca littoralis may have been a species of Poa (see Edgar and Connor 2000 for a summary of the synonymy), it was not thought to be a good fit in that genus (Edgar and Connor 2000); the base of the lemma lacks a web and has a dense crown of short hairs to $0.5-0.8 \mathrm{~mm}$ long, and the apex said to be muticous or mucronate. Recent DNA studies (Hunter et al. 2004; Gillespie \& Soreng 2005; Gillespie et al.2007, Soreng et al.2007) have made it clear that A. littoralis and A. pubinervis are species of Poa. Gillespie and Soreng (2005) suggest that Poa billardierei (Spreng.) St.-Yves is the appropriate combination in Poa to use for A. littoralis; the epithet is probably sufficiently distinct from the Australian P. labillardierei Steud. (also naturalised in New Zealand) to prevent confusion. Gillespie and Soreng (2005) also point out that most of the characters of Poa billardierei (A. littoralis s.lat., including A. pubinervis) thought to exclude it from Poa occur elsewhere in that genus. 
Hunter et al. (2004) also suggest that both the genera Festucella and Hookerochloa should be recognised as '...the taxa differ in a wide range of quantitative and qualitative vegetative and reproductive characters.... They list 14 characters; three of these as discontinuous, viz., (i) leaf blade inrolled vs folded, (ii) glumes smooth vs scabrous, and (iii) caryopsis $3.8-4.5 \mathrm{~mm}$ vs $2.6-3.4 \mathrm{~mm}$ long. They have two other characters whose character states are worded differently but actually do not differ significantly, viz., (i) abaxial palea surface glabrous to hairy vs glabrous or scabrous, and (ii) habitat descriptions of 'open montane to subalpine forest and grassland' versus 'swampy subalpine to alpine forest and grassland'. We maintain there are two further distinguishing characters that they omitted: leaf width, and a few characters related to this (Jacobs 1990); and epidermal features, where Festucella has a coarsely scabrous adaxial epidermis and Hookerochloa has a smooth to scabrid adaxial epidermis (Soreng \& Gillespie 2007).

As a new edition of Wheeler et al. (2002) is about to be prepared, it has become necessary to clarify the situation and provide any necessary new combinations.

\section{Methods}

A total of 39 specimens of each species of Festucella and Hookerochloa were examined. The specimens (all held at NSW) covered the full geographic range and variation observed in these taxa. The following characters were investigated:

(i) leaf blade inrolled vs folded,

(ii) glumes smooth vs scabrous, and

(iii) caryopsis length.

Cladograms from Hunter et al. (2004), Gillespie and Soreng (2005) and Gillespie et al. (2007) and analyses from Gillespie and Soreng (unpublished data) were used to decide on the generic placement of the species.

The situation with Austrofestuca pubinervis was assessed from the literature and specimens.

\section{Results}

\section{Hookerochloa/Festucella}

(i) Leaf blade inrolled vs folded: the leaves are folded or flat in both species; Alexeev (1987) illustrated a folded transection of Festucella eriopoda while describing the blade as inrolled. As indicated in Jacobs (1990), the character distinguishing the two is basically leaf width. The leaves of $F$. eriopoda can be very narrow and the folded portion in some cases very small, giving the appearance of rolling. The situation is clearer on specimens with larger leaves.

(ii) Glumes smooth vs scabrous: the glumes of both species can be smooth or scabrous. From the specimens held at NSW, smooth glumes are more common in H. hookeriana than in F. eriopoda, opposite to the situation suggested in Hunter et al. (2004). We conclude that this character does not significantly differ between the species. 
(iii) Caryopsis length: caryopses were difficult to find in any specimen, but enough were found to indicate that the stated difference does not hold. The figures supplied here would be slightly less than the full potential size, though it is not clear by how much. F. eriopoda had seed 3.0-4.1 $\mathrm{mm}$ long (mean $=3.6, \mathrm{n}=5$ ) and H. hookeriana seeds 3.0-4.2 mm long (mean $=3.6, \mathrm{n}=8$ ). Clearly, in our sample, there were no differences in the seeds lengths between the species.

(iv) Other characters: there is a difference in leaf blade width and some associated characters such as number of lateral veins in the blade (Jacobs 1990). There may be a tendency for the degree of hairiness of the abaxial palea surface to differ, but not in any disjunct way. There is a difference in the degree of scabridity of the adaxial leaf surface (Soreng \& Gillespie 2007). The important difference in the habitat differentiators suggested by Hunter et al. (2004) is that H. hookeriana tends to grow at higher altitudes than F. eriopoda.

These are certainly useful characters to discriminate species but are inadequate to use to separate the species into two genera.

The ITS sequences in Hunter et al. (2004) and plastid sequences in Soreng et al. (2007) show good support for a clade containing both species, with Arctagrostis latifolia as sister to that clade. While there is good support for several of the final groupings in the cladograms, there is little resolution of the relationships between the groups, a common occurrence with grass gene sequences.

Gillespie and Soreng (2005) did not include either Festucella or Hookerochloa in their published cladograms, though they did point out that both genera shared slender awned lemmas and a few other characteristics with Poa subgen. Andinae, now proposed as a new genus Nicoraepoa (Soreng \& Gillespie 2007). Gillespie and Soreng (unpublished data) also ran analyses with both Festucella and Hookerochloa; they found that:

(i) in cpDNA trnT-trnF analyses Festucella resolves in a clade with Arctagrostis (but this is not well supported being based on a single shared character), and this pair unites in a polytomy with Hookerochloa and species of Nicoraepoa (with relationships in this clade poorly resolved); and

(ii) in ITS analyses Festucella and Hookerochloa are sister taxa, Arctagrostis forms a clade with Nicoraepoa, and these four taxa are united in a strongly supported clade.

In a separate analysis using three independent chloroplast gene sequences (Soreng et al. 2007) Festucella and Hookerochloa are sisters in a polytomy with Arctagrostis and Nicoraepoa, without any other taxa, and Poa billardierei (actually P. pubinervis) is resolved with Poa.

These results are similar to those of Hunter et al. (2004).

\section{Austrofestuca pubinervis/Austrofestuca littoralis}

The lemma apex in both species is entire or occasionally minutely notched with the stout keel extending at the apex as a minute but firm nub $<0.1 \mathrm{~mm}$ long behind the marginal dents (in side view). An apex with a stout short awn (rarely up to $3 \mathrm{~mm}$ long) develops occasionally in Poa sect. Parodiochloa (C.E. Hubb.) Soreng. These mucros or awns are thicker than the more delicate awns that extend from the lemma apices in the two Hookerochloa species. 
While the ITS sequences in Hunter et al. (2004) show A. littoralis as a clade within Poa, few Poa species and no other Australian species were included in the analysis. Gillespie and Soreng (2005) included six other Australian species in their cpDNA analysis of relationships in Poa and A. pubinervis aligns well with the other Australian species in the same major clade in Poa. Similar results were obtained with plastid sequence data by Gillespie et al. (2007).

Plastid and ITS data for 'Austrofestuca pubinervis' or 'Poa billardierei' s.l., generated by Gillespie and Soreng (2005) and Gillespie et al. (2007: unpublished data) and discussed by Soreng et al. (2007) are all derived from collections of $A$. pubinervis from Western Australia (Peterson et al. 14510). When A. pubinervis is included in ITS and cpDNA analyses (Gillespie et al. 2007, unpublished data) with sequences of $P$. billardierei s.str. from New Zealand (from Hunter et al. 2004), they come out together with other Australian Poa species within Poa.

Hunter et al. (2004), quoting Weiller et al. (1995 et seq.), suggest that A. pubinervis is doubtfully distinct from Poa billardierei [as A. littoralis]. The url of Weiller et al. that is quoted no longer appears active but, presuming it is the same text that appears in another url suggesting the same citation, then Weiller et al. do say there is some doubt as to the distinctness of $A$. pubinervis but still treat it as a distinct species and do not synonymise the name. The situation is still as suggested by Simon (1986) viz., the name was provided by Vickery (1939) to replace an earlier invalid name (Festuca triticoides Steud.), and the species is maintained as separate in NSW and BRI. There is variation in the hairiness of the lower lemma, as stated by Weiller et al. (1995 et seq.): the Western Australian specimens have lemmas that are hairy below (i.e., P. pubinervis s.str.); the specimens from New South Wales have a lemma that is glabrous below (i.e., P. billardierei s. str.). Both forms (species) grow in Victoria, Tasmania and New Zealand. The only South Australian specimens seen were too mature to characterise lemma vestiture. It is clear that these two species would benefit from further study. Synonymising the two names is only one option and there are insufficient data to support this option over any other at this stage.

\section{Discussion}

\section{Hookerochloa/Festucella}

The characters that Hunter et al. (2004) put forward for maintaining Festucella and Hookerochloa as separate genera are either erroneous or not discontinuous. The situation has not changed since Jacobs (1990) noted that the two species were only reliably separated by leaf blade width or associated characters. There are no good characters to separate the two into different genera.

The sequence data do not support either combining the two into one genus or recognising two genera, but do provide support for treating them as sister taxa. The data do suggest that consideration needs to be given to the relationships with Arctagrostis and Poa subgen. Andinae (for discussion of the latter see Soreng and Gillespie (2007) where this section is elevated to the rank of genus as Nicoraepoa). Arctagrostis is variously treated as having 1-4 species but all have a single floret per spikelet, acute to mucronate lemmas and a glabrous callus, quite distinct from the floral morphology of both Festucella and Hookerochloa, which have long-acute awned lemmas and a hairy 
callus. Nicoraepoa is sister to the three genera above and is probably most similar morphologically to Festucella and Hookerochloa but the sequence data do not support treating all three in one genus. To do so would require including Arctagrostis and, if equivalence was to be even vaguely maintained, would require the amalgamation of several morphologically diverse genera from the subtribe Poinae. Both Festucella and Hookerochloa were published at the same time and have equal priority. We have chosen to combine both under Hookerochloa.

Austrofestuca pubinervis

This species undoubtedly belongs in Poa. Its status with respect to Poa billardierei would certainly benefit from further investigation, but the evidence thus far suggests it is worth maintaining until more complete studies are available. Consequently a new combination is provided in Poa.

\section{New Combinations}

Hookerochloa eriopoda (Vickery) S.W.L.Jacobs, comb. nov.

Basionym: Festuca eriopoda Vickery (1939: 10-11).

Synonyms: Festucella eriopoda (Vickery) E.B.Alexeev (1985: 104); Austrofestuca eriopoda (Vickery) S.W.L.Jacobs (1990: 602).

Type: Blue Mountains, Kanimbla Valley (Mt Victoria) J.J. Fletcher 24.12.1892 (K).

Poa pubinervis (Vickery) S.W.L.Jacobs, comb. nov.

Basionym: Festuca pubinervis Vickery (1939: 7), nom. nov. for Festuca triticoides Steudel (1855 [1854]: 315) non Lamarck (1791).

Synonyms: Austrofestuca pubinervis (Vickery) B.K.Simon (1986: 241); Austrofestuca triticoides (Benth.) E.B.Alexeev (1987: 15); Schedonorus littoralis var. triticoides Bentham (1878: 656).

Type: South-west Australia, Drummond 150, (K) n.v.

\section{References}

Alexeev EB (1976) Austrofestuca (Tzvel.) E. Alexeev comb. nov. a new genus of the family Poaceae from Australia. Byulleten Moskovskogo Obshchestva Ispyteley Prirody Biologia 81: 55-60.

Alexeev EB (1985) New genera of grasses. Byulleten Moskovskogo Obshchestva Ispyteley Prirody Biologia 90: 102-109.

Alexeev EB (1987) Festuca L. et genera proxima (Poaceae) in Australia et Tasmania. Novitates Systematicae Plantarum Vascularum 24: 5-17.

Bentham G (1878) Flora Australiensis vol. 7. (L. Reeve \& Co.: London)

Clayton WD \& Renvoize SA (1986) Genera Graminum - grasses of the world. Kew Bulletin Additional Series XIII.

Edgar E \& Connor HE (2000) Flora of New Zealand vol V Gramineae (Manaaki Whenua Press: Lincoln).

Gillespie LJ \& Soreng RJ (2005) A phylogenetic analysis of the bluegrass genus Poa based on cpDNA restriction site data. Systematic Botany 30: 84-105. 
Gillespie LJ, Archambault A \& Soreng RJ (2007) Phylogeny of Poa based on trnT-trnF sequence data: major clades and basal relationships. Pp. 420-434 in Columbus JT, Friar EA, Porter JM, Prince LM \& Simpson MG (eds) Monocots: comparative biology and evolution - Poales. Aliso 23: 420-434.

Hunter AM, Orlovich DA, Lloyd KM, Lee WG \& Murphy DJ (2004) The generic position of Austrofestuca littoralis and the reinstatement of Hookerochloa and Festucella (Poaceae) based on evidence from nuclear (ITS) and chloroplast (trnL-trnF) DNA sequences. New Zealand Journal of Botany 42: 253-262.

Jacobs SWL (1990) Notes on Australian grasses (Poaceae) Telopea 3: 601-603.

Simon BK (1986) Studies in Australian grasses: 2 Austrobaileya 2: 238-242.

Soreng RJ, Davis JI \& Voionmaa MA (2007) A phylogenetic analysis of Poaceae tribe Poeae s.lat. based on morphological characters and sequence data from three chloroplast-encoded genes: evidence for reticulation, and a new classification for the tribe. Kew Bulletin 62: 425-454.

Soreng RJ \& Gillespie LJ (2007) Nicoraepoa (Poaceae, Poeae), a new South American genus based on Poa subgenus Andinae, and emendation of Poa section Parodiochloa of the sub-Antarctic islands. Annals of the Missouri Botanical Garden. 94: 821-849.

Steudel EG (1854) 1855 [1853-1854]) Synopsis Plantarum Glumacearum, vol. 1.

Vickery JW (1939) Revision of the indigenous species of Festuca Linn. in Australia. Contributions from the New South Wales National Herbarium 1: 5-15.

Weiller CM, Henwood MJ, Lenz J \& Watson L (1995 et seq.) Pooideae (Poaceae) in Australia descriptions and illustrations. http://muse.bio.cornell.edu/delta/ [this url does not appear to be currently active but the text can, at least for now, be found on http://delta-intkey.com/ pooid/www/descr065.htm where it gives the previous url for citation purposes]

Wheeler DJB, Jacobs SWL \& Whalley RDB (2002) Grasses of New South Wales $3^{\text {rd }}$ edition. (Botany, University of New England: Armidale, Australia).

Manuscript received 15 October 2007, accepted 15 May 2008 